\title{
水稲用除草剤カフェンストロール・ピラゾスルフロンエチル 顆粒水和剤の開発およびその施用技術の確立
}

\author{
湏田暢之 ${ }^{* *}$ ・若山健二 ${ }^{* * * *}$ ・松本直樹 ${ }^{* *} \cdot$ 釜谷拓和 ${ }^{* *} \cdot$ 縄巻 勤*
}

キーワード：水稲用除草剤, 顆粒水和剤, 省力, 力 フェンストロール，ピラゾスルフロンエチル

Key words: rice herbicide, water dispersible granules, labor saving, cafenstrole, pyrazosulfuron-ethyl

日本の農業は，高齢化，大規模化，自由化などの 流れが起こり,省力化が求められる時代に突入した。 なかでも薬剤施用技術の改善に対する期待は大きく, 水稲用除草剤の新剂型もその一つである。カフェン ストロール・ピラゾスルフロンエチル顆粒水和剤は, 省力化，軽量化，省労働化，省資源を目的として開 発された新しいタイプの水稲用除草剤であり, 平成 9 年（1997年）より日本での販売が開始された。こ

\footnotetext{
所属機関：日産化学工業株式会社

*農業化学品事業部

厂101-0054 東京都千代田区神田錦町 3-7-1

**生物科学研究所

T349-0218 埼玉県南埼玉郡白岡町大字白岡 1470

***中央研究所

二274-8507 千葉県船橋市坪井町722

****札幌支店

T060-0001 札幌市中央区北一条西 5-3

Masayuki Hamada**, Kenji Wakayama****, Naoki Matsumoto***, Hirokazu Kamatani***, Tsutomu Nawamaki*: Development of Water Dispersible Granules of Cafenstrole and Pyrazosulfuron-ethyl Mixture as a Rice Herbicide Formulation and it's Application Technology. *Agricultural Division, Nissan Chemical Industries, Ltd. ${ }^{*}$ Shiraoka Research Station of Biological Science, Nissan Chemical Industries, Ltd. *** Central Research Institute, Nissan Chemical Industries, Ltd. ${ }^{* * *}$ Sapporo Sales Branch, Nissan Chemical Industries, Ltd. *Chiyoda-ku, Tokyo, 101-0054, Japan. **Shiraoka-machi, Saitama, 349-0218, Japan ${ }^{* * *}$ Tsuboi-cho, Funabashi-shi, Chiba, 274-8507, Japan **** Chuo-ku, Sapporo, 060-0001, Japan (1999年10月 9 日受理)
}

の薬剤の開発にあたって, 顆粒水和剤を水稲用に適 用するための製剤処方の確立，その拡散性の評価， 散布方法の検討, 専用散布器の選定および水稲用除 草剤としての性能など種々の検討を行った。ここで は, 日本で初めて水稲用顆粒水和剤を完成させるま でに至った開発研究の概要を述べたい。

本研究の遂行にあたり懇切なご指導を賜った国お よび道府県の農業試験場, 指導機関, 大学関係者な らびに財団法人日本植物調節剤研究協会の方々に心 より感謝の意を表する。

\section{1. 水稲用除草剤カフェンストロール・ ピラゾスルフロンエチル顆粒水和剤の特徵}

水稲用除草剂カフェンストロール・ピラゾスルフ ロンエチル顆粒水和剤は, これまで, 日本の水稲用 一発処理剤として使用されてきた粒剤, フロアブル 片, ジャンボ剤の凨型とは異なる顆粒水和剤という 新しい剤型である(第 1 図)。10アール当たりの製剤 量は $60 \mathrm{~g}$ で, これまでの剂型の約 $1 / 5 \sim 1 / 50$ の重量と なり，軽量・コンパクト化された。例えば 3 キロ粒 剤 ( $3 \mathrm{~kg} / 10$ アール) と比較すると, 補助成分を 2940 $\mathrm{g}$ 削減でき, 省資源化へとつながった。また流通上, 軽労働化され, 収納も省スペース化された。使用方 法については後ほど詳しく述べるが，その特色ある 方法を可能にしたのは, 少量の水にも溶けやすい顆 粒水和の製剂化と，その水溶液に有効成分の拡散性 を持たせたことであった。すなわち，これまで他の 分野で用いられた顆粒水和剤以上の顆粒の速やかな 水和性や水中崩壊性と, 有効成分の分散安定性や拡 散性の著しい向上に成功したことにある。

有効成分については，ノビエをはじめとする一年 生雑草に高い効果を示し, 残効性に優れるカフェン ストロール（試験名：CH－900）50\%と，低成分で 多年生雑草を含む広範囲の雑草に卓効を示すピラゾ 


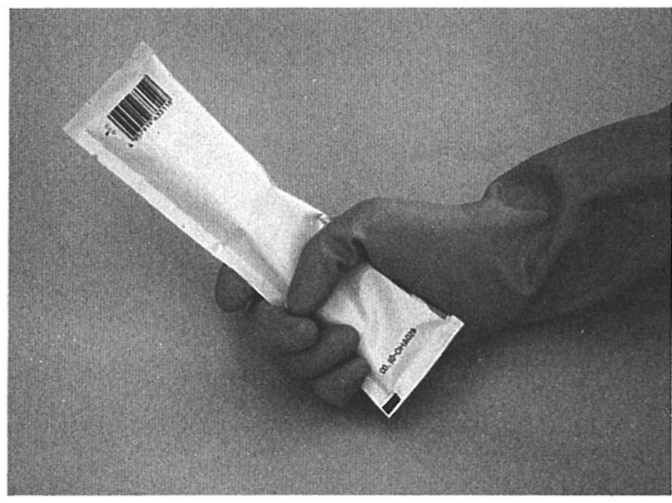

第 1 図 カフェンストロール・ピラゾスルフロンエチル顆 粒水和剤の包装形態

スルフロンエチル（試験名：NC-311) 3.5\%を配合 した。全国的な実用試験の結果, 適用時期が移植後 5 日〜ノビエ 2.5 葉期まで使用可能な初・中期一発処 理剤として実用性が認められ, 平成 8 年10月29日付 で農薬登録された。

\section{2. カフェンストロール・ピラゾスルフロン}

\section{エチル顆粒水和剤の製剤の確立}

カフェンストロール・ピラゾスルフロンエチル顆 粒水和剤の製剤は, 界面活性剤などの補助剤と製剤 の物理性の関係について検討を行い, その処方を確 立した。物理性は, 水中崩壊性, 懸垂率, 造粒性, 起泡性・消泡性, 過酷試験, 拡散性等について評価 した。

処方検討に際して，リグニンスルホン酸を主成分 とする一般的な顆粒水和剤の処方に, 種々の界面活 性剂を添加して検討した ( $\mathrm{A} \sim \mathrm{D}$ 処方, 第 1 表)。処 方中のキャリアとしては水溶性無機塩を使用し, 界 面活性剤としては, リグニンスルホン酸系に,ナフ タレンスルホン酸系, 硫酸エステル系界面活性剤を 添加し,さらに消泡剤を添加した製郕について, 物 理性の変化を測定した（第 2 表, 第 2 図)。

界面活性剂としてリグニンスルホン酸系単独のA 処方に比べ， B処方のナフタレンスルホン酸系界面 活性剂を加えたものは，造粒性・水中崩壊性・懸垂 率の点で優れていた。特に, 水中崩壊性は 8 回から 4 回と著しく向上した。なお水中崩壊性については $500 \mathrm{ml}$ の散布用ボトルに水 $460 \mathrm{ml}$ を入れ,そこに顆粒 $60 \mathrm{~g}$ を投入した後, ボトルを上下に転倒し, 粒が完全
に溶解するまでの転倒回数を測定した。懸垂率にお いても 2 時間後の值で $90 \%$ から $95 \%$ 以となり, 分 散安定性も改善された。しかし，B処方では過酷試 験後の水中崩壊性や毷垂率の悪化が認められた。そ こで, B処方に硫酸エステル系界面活性剂を加える ことで ( $\mathrm{C}$ 処方 $)$, 物理性の経時変化すなわち過酷試 験後の水中崩壊性等を抑制した。また顆粒水和剤を 水に希釈し, 散布用ボトルや専用加圧散布器を用い て散布するとき, 泡立ちのため, 懸濁液の散布器か らの排出性が悪くなる可能性があり,さらに消泡剤 の添加が必要であった( $\mathrm{D}$ 処方)。D処方では, 水中 崩壊性や懸垂率などの物理性も全く変化なく, 優れ た製剤処方を確立することができた。

さらに, 水稲用顆粒水和剤は, 畑作用などの従来 の顆粒水和剂と異なり, 田面水中での有効成分の優 れた拡散性が要求される。そこで各処方の拡散性の 検討を行った(第 2 図)。拡散性試験は, $0.25 \mathrm{~m} \times 4$ $\mathrm{m}$ の水槽内の水深を $5 \mathrm{~cm}$ にして, 水槽の端に希釈 液を処理し, 24 時間後の有効成分の濃度分布を $\mathrm{H} \mathrm{P}$ L C により測定した。理論均一濃度は, カフェンス トロールが600ppb, N C - 311が42ppbである。その 結果, $\mathrm{A}$ 処方に対し, 種々の界面活性剂を組み合わ せていった $\mathrm{B}, \mathrm{C}, \mathrm{D}$ 処方の順に拡散性が向上した。 $\mathrm{D}$ 処方は，有効成分のカフェンストロールおよびピ ラゾスルフロンエチルとも処理地点から最も遠くま で拡散した。

上記のような検討から，カフェンストロール・ピ ラゾスルフロンエチル顆粒水和剤は, D処方を最終 処方とし，日本で初めて水稲用への適用が可能とな った処方を完成させた。

\section{3. カフェンストロール・ピラゾスルフロン エチル顆粒水和剤の施用方法の特色}

カフェンストロール・ピラゾスルフロンエチル顆 粒水和剈は, 10 アール当たり $60 \mathrm{~g}$ の顆粒水和剤を水に 希釈して $250 \sim 500 \mathrm{ml}$ の薬液にして使用する。基本的 な散布方法は，次のとおりである。

（1）容器に水を先に入れる $(500 \mathrm{ml}$ 希䣋の場合, 10 ア ール当たり $460 \mathrm{ml}$ の水を入れる)。

（2）次に顆粒水和剂を入れる(10アール当たり $60 \mathrm{~g} の$ 薬羭が入った袋を 1 袋)。

（3）よく振って溶かす（容器にふたをし， 5 回以上 振って, 薬剤の溶解を確認する)。 
第 1 表 カフェンストロール・ピラゾスルフロンエチル顆粒水和剤の処方検討

\begin{tabular}{|c|c|}
\hline 検討処方 & 分* \\
\hline A 処 方 & リグニンスルホン酸系十水溶性無機塩（キャリア） \\
\hline B 処方 & リグニンスルホン酸系+ナフタレンスルホン酸系十水溶性無機塩（キャリア） \\
\hline C 処方 & リグニンスルホン酸系＋ナフタレンスルホン酸系＋硫酸エステル系＋水溶性無機塩（キャリア） \\
\hline $\mathrm{D}$ 処方 & リグニンスルホン酸系+ナフタレンスルホン酸系十硫酸エステル系＋水溶性無機塩 $($ キャリア $)+$ 消泡剤 \\
\hline
\end{tabular}

*各処方には有効成分のカフェンストロールとピラゾスルフロンエチルが含まれる

第 2 表 検討処方の物理的特性

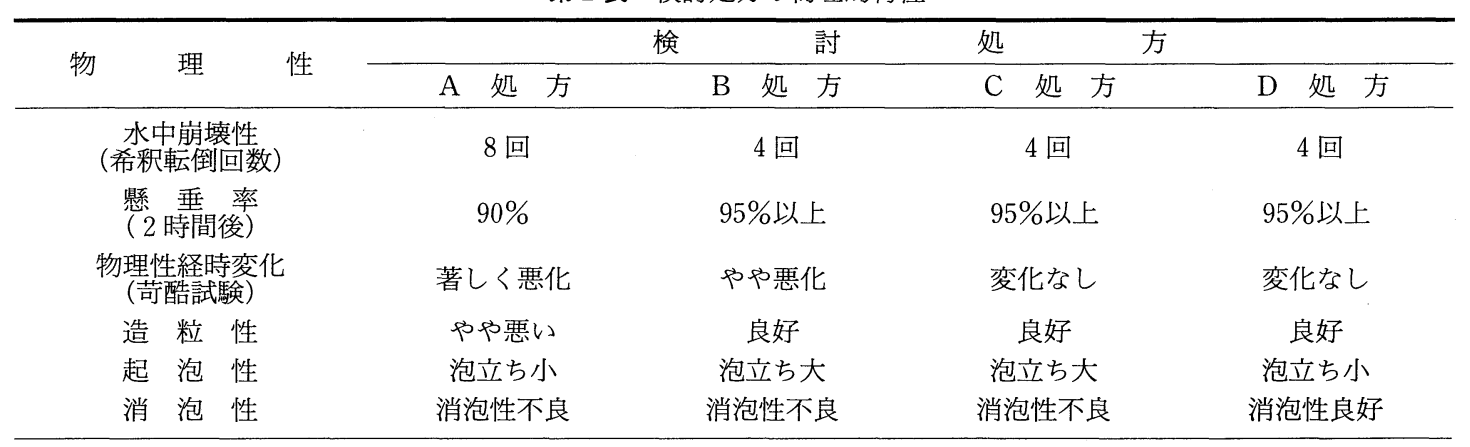
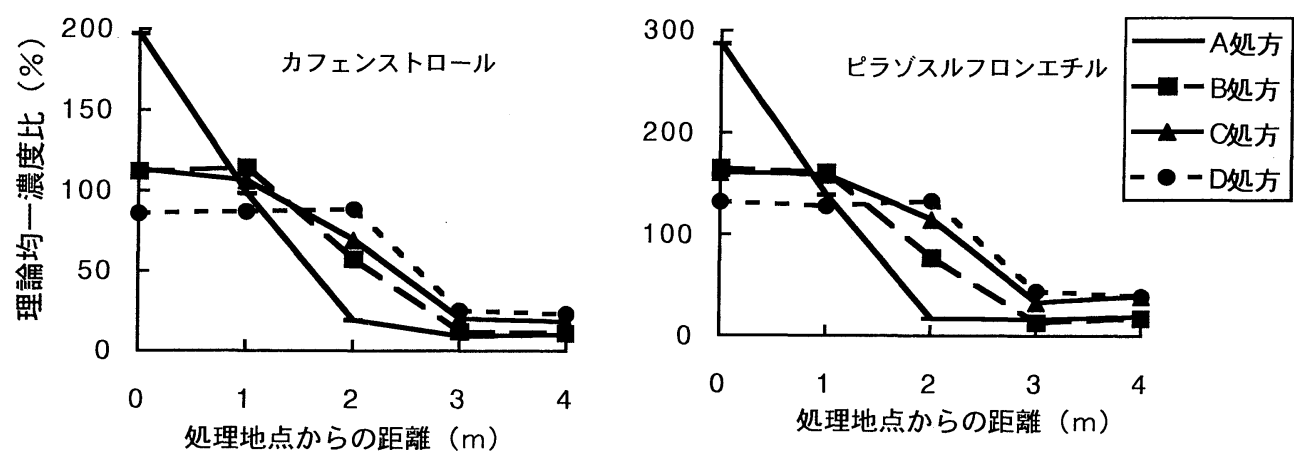

第 2 図 検討処方の拡散性 $(0.25 \mathrm{~m} \times 4 \mathrm{~m}$ の水槽試験, 24時間後の水中濃度 $)$

（4）水田に散布する (畦畔から $2 \sim 3 \mathrm{~m}$ 進むごとに 1 回ずつ水田へ向けて散布する)。

希釈した薬液は，粘性はほとんどなく水に近い状 態であるために, 散布器を多種にわたって選択でき る。現在, この顆粒水和剤用に開発されている散布 器は, $500 \mathrm{ml}, 1 \ell$ および $1.35 \ell$ (北海道向け) の各 専用ボトル, $2 \ell$ 専用加圧散布器, 背負い式動力散 布機の専用ノズルなどがある(第 3 図)。専用ボトル は, 簡単に散布の準備ができ, 手軽に畦畔から散布 できる。ここで特筆すべきことは, 専用ボトルのサ イクル利用により, 産業廃棄物となる農薬用プラス
チック容器ゴミの発生を抑えることである。専用加 圧散布器は, 水稲用一発処理剂としては, これまで にない散布器である。顆粒水和剤を溶かした後, ポ ンプを押して加圧することで散布飛距離が伸び, 専 用ボトルによる手振りの $3 \sim 4 \mathrm{~m}$ から, 2 倍の 6 ～ 8 $\mathrm{m}$ まで薬液が飛ぶようになった(第 4 図)。また手振 り散布よりも腕を振る負荷が少なくて済み, 大規模 な水田の散布においても労働負荷が軽減される。背 負い式動力散布機の専用ノズルは, さらに大面積の 固場等で有効な散布手段である。なお留意点として, いずれの散布器もカフェンストロール・ピラゾスル 


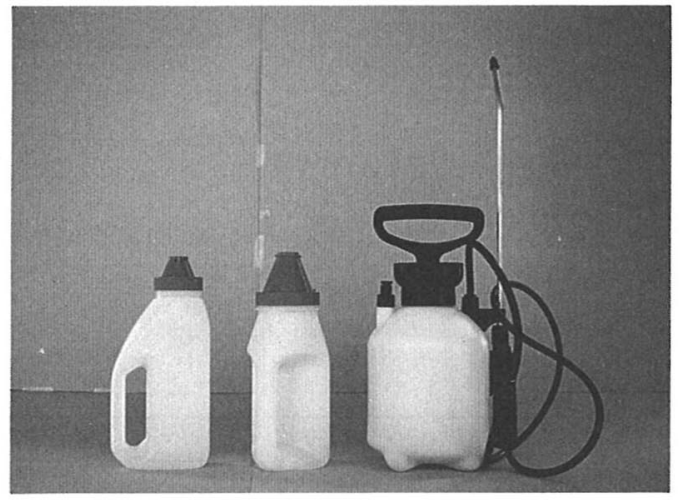

第 3 図 カフェンストロール・ピラゾスルフロンエチル顆 粒水和剤の専用散布器

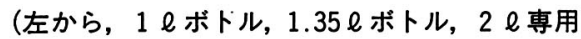
加圧散布器)

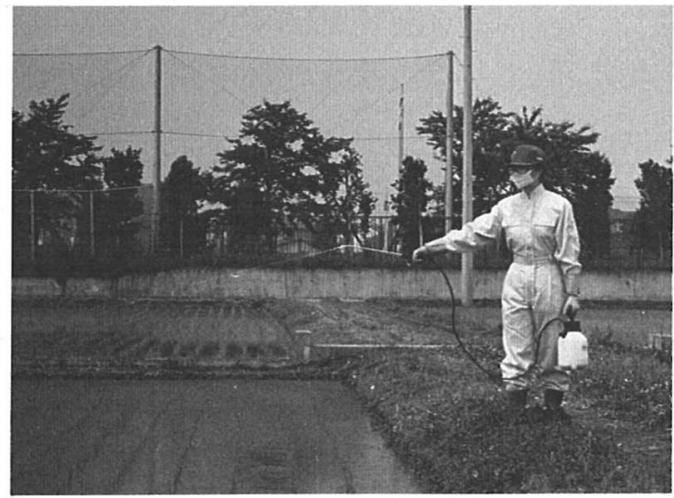

第 4 図 $2 \ell$ 専用加圧散布器による散布
フロンエチル顆粒水和剤用の専用散布器とし, 水稲 以外の作物へは使用を避けることが望ましい。

\section{4. カフェンストロール・ピラゾスルフロン エチル顆粒水和闵の拡散性と除草効果}

カフェンストロール・ピラゾスルフロンエチル顆 粒水和剤の有効成分の拡散性と除草効果を 30 アール の围場で検討した。埼玉県南埼玉郡白岡町の30アー ル $(30 \mathrm{~m} \times 100 \mathrm{~m})$ の水田に, 平成 7 年 6 月 3 日にイ ネを移植し, 薬剤の処理を移植 9 日後の 6 月 12 日に 行った。処理時の条件は, 田面水の水温 $24^{\circ} \mathrm{C}$, 湛水 深 $5 \mathrm{~cm}$, 風速 $2 \mathrm{~m} /$ 秒以下であった。薬剤処理は, 希釈液量を顆粒水和剤 $60 \mathrm{~g}$ あたり $500 \mathrm{ml}$ にし, 水田の 周縁部の畦畔から $1 \ell$ ボトルによる手振り散布を行 い（周縁散布）, 合計 $1.5 \ell$ のカフェンストロール・ ピラゾスルフロンエチル顆粒水和剤希釈液を処理し た。処理 3 日後に水田の対角線上 5 地点より田面水 を採取し，有効成分の濃度を分析した。除草効果・ イネに対する影響は，処理 4 週間後に調査した。

処理 3 日後の田面水の有効成分濃度は, カフェン ストロール, ピラゾスルフロンエチルとも, 採取し た 5 地点でほぼ同程度の值を示し，速やかに成分が 搪散し，均一になることが示された(第 5 図)。処理 4 週間後の除草効果は, ノビエ, ホタルイに対し極 大の効果を示し，イネに対する薬害も認められなか った (第 3 表)。

以上のように，カフェンストロール・ピラゾスル フロンエチル顆粒水和剤は，拡散性に優れた製剤で

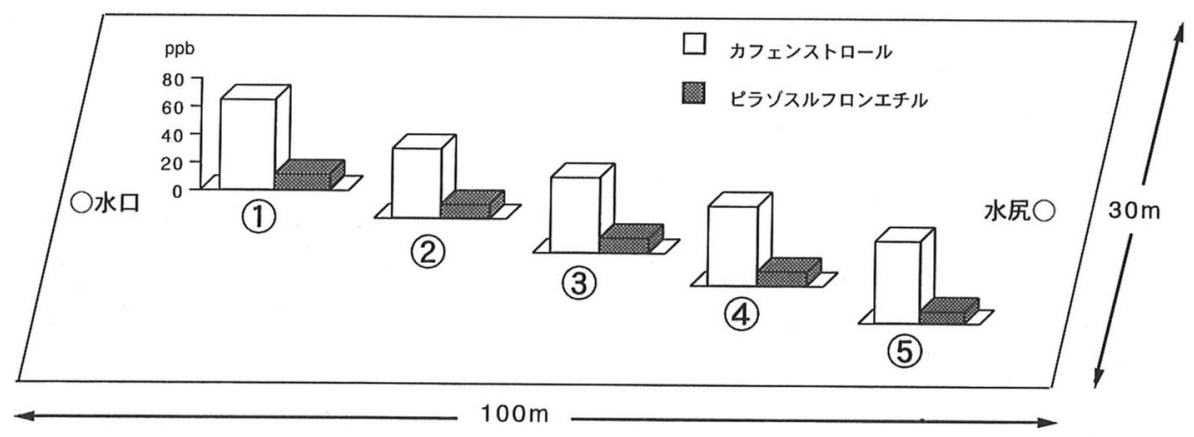

第 5 図 カフェンストロール・ピラゾスルフロンエチル顆粒水和剤の周緑散布における有効成分の拡散性 （処理 3 日後における有効成分の田面水中の濃度） 
第 3 表 カフェンストロール・ピラゾスルフロンエチル顆粒水和剤の周縁散布に抢ける除草効果

\begin{tabular}{|c|c|c|c|c|}
\hline \multirow{2}{*}{$\begin{array}{c}\text { 調査地点 } \\
\text { (第 } 5 \text { 図参照) }\end{array}$} & 除 & 草 & 効 & \multirow{2}{*}{ イネに対する影響 } \\
\hline & ノビエ & & ホタルイ & \\
\hline (1) & 9 & & 9 & 0 \\
\hline (2) & 9 & & 9 & 0 \\
\hline (3) & 9 & & 9 & 0 \\
\hline (4) & 9 & & 9 & 0 \\
\hline (5) & 9 & & 9 & 0 \\
\hline 処理時葉齢 & 発生始～1 1 葉 & & 発生前 & 3.5葉 \\
\hline
\end{tabular}

処理 4 週間後の観察評価： $0=$ 影響なし $9=$ 完全枯死

第 4 表 温室内試験におけるカフェンストロール・ピラゾスルフロンエチル顆粒水和剤の除草効果

\begin{tabular}{cccccccc}
\hline \multirow{2}{*}{\begin{tabular}{c} 
薬量 \\
\cline { 2 - 8 }$(\mathrm{WDG} / \mathrm{a})$
\end{tabular}} & \multicolumn{1}{c}{ ノビエ } & ホタルイ & コナギ & 一年生広葉* & ウリカワ & ミズガヤツリ & $\begin{array}{c}\text { イネに対する } \\
\text { 影 }\end{array}$ \\
\hline 6 & 8.8 & 7.0 & 9.0 & 8.0 & 7.0 & 8.5 & 0 \\
\hline
\end{tabular}

試験規模 $: 0.16 \mathrm{~m}^{3} 、 3$ 反復、薬剤処理時期：ノビエ 2.5 葉期（移植後 17 日）、希釈液量 $: 50 \mathrm{ml} / \mathrm{a}$

数值は、処理 42 日後の観察評価： $0=$ 影響なし〜 $9=$ 完全枯死、*一年生広葉は、アゼナ、キカシグサ

第 5 表 平成 7 年現地圃場試験におけるカフェンストロール・ピラゾスルフロンエチル顆粒水和剤の除草効果

\begin{tabular}{|c|c|c|c|c|c|c|c|}
\hline \multirow{2}{*}{$\begin{array}{l}\text { 試験地 } \\
\text { (移植日) }\end{array}$} & \multirow{2}{*}{ 処理時期 } & \multirow{2}{*}{$\begin{array}{c}\text { 調査日 } \\
\text { (移植後日数) }\end{array}$} & \multicolumn{2}{|r|}{ 除 } & 効 & 果 & \multirow{2}{*}{$\begin{array}{c}\text { イネに対する } \\
\text { 影 響 }\end{array}$} \\
\hline & & & ノビエ & ホタルイ & コナギ & 一年生広葉* & \\
\hline \multirow{2}{*}{$\begin{array}{l}\text { 宮城県玉造郡 } \\
\text { ( } 5 \text { 月10日) }\end{array}$} & \multirow{2}{*}{$\begin{array}{l}\text { 移植後 } 7 \text { 日 } \\
\text { ノビエ } 2.5 \text { 葉期 }\end{array}$} & \multirow{2}{*}{ 40日 } & 9.0 & 8.5 & 9.0 & 9.0 & 0 \\
\hline & & & 8.5 & 8.8 & 9.0 & 9.0 & 0.3 \\
\hline \multirow{2}{*}{$\begin{array}{c}\text { 埼玉県南埼玉郡 } \\
\text { ( } 4 \text { 月20日) }\end{array}$} & \multirow{2}{*}{$\begin{array}{l}\text { 移植後 } 5 \text { 日 } \\
\text { ノビエ } 2.5 \text { 葉期 }\end{array}$} & \multirow{2}{*}{ 32日 } & 9.0 & 8.9 & 8.9 & 9.0 & 0.5 \\
\hline & & & 8.9 & 9.0 & 9.0 & 9.0 & 0.3 \\
\hline \multirow{2}{*}{$\begin{array}{c}\text { 福岡県粕屋郡 } \\
\text { ( } 6 \text { 月11日) }\end{array}$} & \multirow{2}{*}{$\begin{array}{l}\text { 移植後 } 5 \text { 日 } \\
\text { ノビエ } 2.5 \text { 葉期 }\end{array}$} & \multirow{2}{*}{ 30日 } & 8.9 & 9.0 & 9.0 & 9.0 & 0 \\
\hline & & & 8.0 & 9.0 & 9.0 & 9.0 & 0 \\
\hline
\end{tabular}

試験規模： $10 \mathrm{~m}^{2} 、 2$ 反復、薬量：6 WDGg/a、希釈液量： $50 \mathrm{ml} / \mathrm{a}$

数值は、観察評価： $0=$ 影響なし〜 $9=$ 完全枯死、*一年生広葉は、アゼナ、キカシグサ、ミゾハコベ

あり，処理 3 日後には有効成分は水田全体に均一に 拡散し，イネにも安全で, 安定した除草効果を示す ことが明らかになった。

\section{5. カフェンストロール・ピラゾスルフロン エチル顆粒水和剤の適用時期}

カフェンストロール・ピラゾスルフロンエチル顆 粒水和剤の適用時期を検討するために，まず温室内 試験において除草効果を確認した。ノビエの2.5葉期 に薬剂を処理したところ，ノビエをはじめ水田雑草 全般に高い効果を示し，イネに対する影響も認めら れなかった(第 4 表)。そこで日本の地域性を考慮し, 平成 7 年に宮城, 埼玉, 福岡の 3 県で現地戋場試験
を行った。その結果, いずれの処理時期も高い効果 を示し，イネに対する影響も認められず，ノビエ2.5 葉期までの適用が可能なことが示された（第 5 表）。

\section{6. カフェンストロール・ピラゾスルフロン \\ エチル顆粒水和剤の今後の発展}

水稲用除草浏カフェンストロール・ピラゾスルフ ロンエチル顆粒水和剤の開発により, 水稲用一発処 理剂の分野において, 薬剤面では, 軽量・コンパク 卜化, 省資源化, 施用技術の面では，省力化，省労 働化, さらに流通面で, 軽労働化, 省スペース化を 実現することができた。今後さらに異なる有効成分 の組み合わせにより，田植え同時散布や適用時期の 
幅が広い薬剤の開発が可能と考えられる。また施用 技術においても，今回紹介した方法だけでなく，新 たな散布方法についても検討されている。例えば, 水口処理やラジコンヘリ散布は, その適用性が確認
され農薬登録された。以上のような水稲用除草㓮力 フェンストロール・ピラゾスルフロンエチル顆粒水 和剂の特色が生かされ, 日本の除草剂施用技術に貢 献することを望む。 